\title{
Insights into CEFR and Its Implementation through the Lens of Preservice English Teachers in Thailand
}

\author{
Witchuda Phoolaikao ${ }^{1} \&$ Apisak Sukying ${ }^{1}$ \\ ${ }^{1}$ Department of Western Languages and Linguistics, Faculty of Humanities and Social Sciences, Mahasarakham \\ University, Thailand \\ Correspondence: Witchuda Phoolaikao, Department of Western Languages and Linguistics, Faculty of \\ Humanities and Social Sciences, Mahasarakham University, Thailand 44150.
}

Received: April 20, 2021

Accepted: May 12, 2021

Online Published: May 13, 2021

doi: $10.5539 /$ elt.v14n6p25

URL: https://doi.org/10.5539/elt.v14n6p25

\begin{abstract}
The Common European Framework of Reference for language teaching, learning, and assessment (CEFR) provides a guideline for English teaching aids and curriculum development in language courses. It identifies and describes the specific skills that language learners must acquire to improve their English language proficiency for communication (CoE, 2001). In the Thai context, the Ministry of Education (MoE, 2014) has adopted the framework as a practical handbook for reforming English teaching at all levels. However, only a few studies have examined Thai stakeholders' perceptions towards CEFR. As such, the current study investigated preservice English teachers' perceptions of the CEFR in a Thai context. A total of 200 fourth and fifth-year preservice English teachers participated in this study. A mixed-method design was used to collect data via seven-point Likert scale questionnaires and semi-structured interviews. The quantitative findings revealed that the participants had a high level of understanding of the CEFR, specifically in the assessment domain and development of reference level descriptions. By contrast, the qualitative data revealed that Thai preservice teachers have little knowledge of the CEFR, and their understanding of the CEFR was quite limited. Nevertheless, Thai preservice teachers expressed positive views regarding the implementation of the CEFR into classroom practice. Overall, these findings indicate that the preservice English teachers had a poor understanding of the CEFR conception, which suggests that Thai stakeholders must raise awareness regarding the proper implementation of the CEFR and its alignment with the national curriculum.
\end{abstract}

Keywords: Common European Framework of Reference for language teaching, learning, and assessing (CEFR), insights, implementation, preservice English teachers

\section{Introduction}

The Common European Framework of Reference for Languages: Learning, Teaching and Assessment (CEFR), launched in 2001 by the Council of Europe $(\mathrm{CoE})$, provides guidelines for language syllabuses, curriculum development, and the design of language materials. It focuses on promoting transparency and coherence in language teaching and learning and has stood as a primary reference point since its conception (CoE, 2001). The framework outlines what language learners must learn to enhance English language proficiency for communication and the knowledge and skills learners require to perform effectively. The CEFR is also used as a benchmark for English language proficiency in listening, speaking, reading, and writing, at six reference levels (A1-A2 for a basic user; B1-B2 for an independent user; and C1-C2 for a proficient user). These scales are regarded as the criteria to compare the abilities of different language learners (CoE, 2001a; xii).

The CEFR has been generally adopted in language learning, teaching, and assessment across the world, and several studies have examined its effectiveness. For example, Nakatani (2012) investigated whether the use of the communication strategy (CS) identified in the CEFR can boost EFL learners' English proficiency in communication tasks and, more recently, another study examined the impact of assessment practice, based on the CEFR descriptors, on learning outcomes in Swedish tertiary education (Apelgren \& Baldwin, 2018). The integration of pronunciation based on the CEFR-oriented perspective for language learners and teachers has also been explored (Topal, 2019). Interestingly, some studies have reported that many teachers have not adopted the CEFR into their classroom practice despite its popularity and benefits. Indeed, a study conducted in Turkey showed that teachers do not adapt the CEFR issues into their practice (Kır \& Sülü, 2014), and other studies in 
Malaysia reported that a large number of Malaysian teachers did not fully understand how to implement the framework and had limited knowledge of some aspects of the document, including assessment (Uri \& Aziz, 2018; Kok \&Aziz, 2019).

In Thailand, the Ministry of Education (MoE) introduced the CEFR in 2014 as a practical guidebook for teaching English in a Thai context. According to the MoE (2014), the aim was to reform the traditional English teaching to Communicative Language Teaching (CLT) to enhance English proficiency at all education levels in Thailand. The hope was that the CEFR would provide a clear framework for the development of school curricula, syllabuses, teaching methodologies, and assessments for practitioners. To date, not much has been made to explore the implementation of the CEFR framework. Even so, most studies have looked into in-service English teachers' perceptions of the CEFR (Franz \& Teo, 2017; Kanchai, 2019; Phaisannan, Charttrakul, \& Damnet, 2019). Overall, these studies indicated some understanding of the CEFR principles from their perspectives. However, little effort has been made to investigate Thai preservice English teachers' viewpoints about the CEFR and its implementation into classroom practice. Understanding preservice teachers' existing knowledge of the CEFR would raise awareness of the CEFR amongst curriculum planners, academics, researchers and policymakers.

\section{Literature Review}

The CEFR plays an essential role in English language teaching and learning and is a useful tool for curriculum guidelines, English language courses, assessments, and describing language proficiency levels. It is built on four main principles: teaching and learning, assessment, reference level descriptions, and implementation (CoE, 2001). In the domain of learning and teaching, the document highlights that practitioners must highlight the characteristics of the local context when developing language learning curricula. The framework allows states that language teaching should focus on the strengths and weaknesses of the learners and encourage them to achieve the learning goals. The CEFR primarily relies on two approaches, Communicative Language Teaching (CLT) and plurilingualism, in teaching and lesson planning in the classroom. The CLT approach is based on two concepts, tasks and interaction, and involves learning a target language successfully by having meaningful communication in an authentic context. Language use is perceived as purposeful, involving the communication of meaning, which is essential for language users to achieve their goals. Consistent with this approach, the Council of Europe (2001) noted that language learning would be more effective when language is used purposefully. Hence, when using the CEFR in the classroom practice for teaching and lesson planning, the teachers or lesson plan writers should develop tasks and interactions based on the needs, motivations, and characteristics of the learners. Plurilingualism is the other CEFR approach used in language teaching and learning, which focuses on the ability to use more than one language and cultural resource to communicate with people from different contexts (CoE, 2001, 2005, 2018). Lesson plans based on the plurilingual approach should therefore emphasize learners' experiences in their cultural context and teachers should provide the learners with more opportunities to improve plurilingual competence.

The principle of assessment relates to the selection or development of appropriate and feasible materials to measure the abilities of the language learners. First, test developers need to adapt the CEFR to their needs and specify the test purpose. The CEFR can help determine the test purpose by providing four general language proficiency domains: personal, public, occupational and educational (CoE, 2001). The next step is to establish a link to the CEFR. Indeed, the Council of Europe (2001) recommended that the test results refer to the CEFR reference level descriptions. As such, the test developers must demonstrate that the test results can be appropriately interpreted based on the CEFR reference levels (North \& Jones, 2009). The third step is the test production. Importantly, a link to the CEFR should be maintained throughout the test development process (CoE, 2011) and the test should also be examined by experts to identify the criteria and edit the test items to ensure the test can be adapted to local contexts. The final step of developing the test is assessment standards. The Cambridge ESOL (2011) stated that the test results should indicate the CEFR proficiency level, which requires a specific process for maintaining the standards over time. For example, tests should be based on the clear and comprehensive 'Can-Do' scales found in the CEFR (e.g., North \& Jones, 2009) and standardization training should be provided to ensure a single, shared interpretation of the rating scale. Finally, experts should monitor ratings to ensure that they do not vary from the intended standard.

The CEFR reference level descriptions aim to bring transparency to language teaching and are designed to build a variety of teaching courses that support plurilingual teaching $(\mathrm{CoE}, 2005)$. The use of reference level descriptions is based on two principles (Cambridge ESOL, 2011). First, reference level descriptions are tools for language stakeholders to bolster curriculum design or test specifications. Second, reference level descriptions can be used in various ways and, therefore, language users must decide a priori on a range of factors, such as the learners' proficiency levels, age and educational background, first language, and reasons for learning English. Reference level descriptions can also identify what language materials to include for teaching and testing at each CEFR level. 
Moreover, language practitioners and curriculum planners can adapt already published reference levels of descriptions to their own contexts.

The framework also provides a comprehensive descriptive scheme of language competence and a set of common reference levels (A1-C2) in illustrative descriptor scales to identify learners' linguistic abilities (Cambridge ESOL, 2011). Indeed, the CEFR has become the standard reference level of language competence on a global scale and is used to develop language teaching, learning, and testing methods (Morrow, 2004). The CEFR is based on an action-oriented approach that focuses on communicative language activities and strategies. Can-Do descriptors are also included that demonstrate learners' proficiency in five skills - listening, reading, writing, spoken interaction, and spoken production - at six levels, ranging from A1 (for beginners) to C2 (for those who have mastered the language).

Several studies on CEFR implementation have been conducted in English as a foreign or second language contexts. For example, Topal (2019) examined how pronunciation could be integrated into language learning using the CEFR-oriented perspective, and Apelgren \& Baldwin (2018) investigated the effect of the CEFR descriptors on assessments and learning outcomes in Swedish university settings. Other studies have also investigated the practitioners' perceptions or attitudes towards the CEFR (Duong \& Trinh, 2014; Kitr \& Sulu, 2014). Overall, these studies showed that teachers rarely used the CEFR framework in their English teaching. Moreover, even English teachers who had partially adopted the framework to assess language proficiency still required more guidance on how to use the CEFR to design tests and curricula and how to apply the framework into their teaching strategies (Hai, 2018; Minh Ngo, 2017; Tiep, 2017). Another study investigating Uzbekistani teachers' perceptions regarding the usefulness and impact of the CEFR found that, overall, these teachers had positive perceptions of implementing the CEFR in Uzbekistan (Musoeva, 2019). A similar study by Díez-Bedmar \& Byram (2019) assessed Spanish teachers' beliefs and perceptions toward the CEFR. It was found that while most of the participants had positive perceptions regarding the impact of the CEFR, some teachers also had limited knowledge of the CEFR (Díez-Bedmar \& Byram, 2019). A recent study by Tosun \& Glover (2020) studied eight Turkish teachers' knowledge of the CEFR and looked at how teachers apply the CEFR and ELP in Turkey. The findings revealed participants' understanding that the CEFR is an essential and beneficial guideline for English language teaching classrooms. However, the teachers also stated that they knew little about the CEFR because they lacked training in the CEFR in all domains. These results are in line with a study by Celik (2013), who found that public school teachers have little knowledge of the CEFR. A similar study aimed to explore 105 state and private school teachers regarding viewpoints on the use of CEFR and its implementation in their teaching. The data analysis revealed that most of the participants had a general understanding of the CEFR. More specifically, private school teachers had adequate knowledge of the CEFR because they have got training concerning the CEFR than public school teachers (Yakışık \& Gürocak, 2018). Another qualitative study by Yüce \& Mirici (2019) aimed to examine 11 EFL language teachers, who were chosen purposefully, regarding the implementation of the ninth grade EFL program about the CEFR. The data showed that the CEFR descriptions were not suited to the 9th grade EFL program. Besides, the results revealed that insufficient hours affected the unsuccessful implementation of CEFR in class (Yüce \& Mirici, 2019), which results are consistent with a study by Alih, Yusoff \& Abdul (2020), who found that the teachers lacked sufficient support to implement the CEFR in English classrooms.

Despite its popularity, the implementation of CEFR has received criticism. The first criticism of the CEFR is the ambiguous descriptors for each level. North (2010) argued that the CEFR descriptors limited the descriptions of learners' performance and were based on teachers' views, not second language acquisition (SLA). Davidson \& Fulcher (2007) also noted that the quality and validation of the CEFR descriptive scales could affect the development of language tests. They stated that the descriptors were not designed for developing language tests as the descriptors blend the roles of language learners within a single stage, and not all descriptors refer to specific contexts (Davidson \& Fulcher, 2007).

The second criticism is the difficulty in implementing the CEFR in the language curriculum. Faez et al. (2011) found that the adaptation of the document in the classroom was unsuccessful because it was difficult to understand. Moreover, McNamara (2011) argued that the CEFR did not consider the sets of cultural values and the aims of the language syllabuses. For instance, a case study by De Mejia (2011) in Colombia revealed that the teachers held negative attitudes towards the implementation of the CEFR as a guiding reference to enhance English language teaching. The teachers believed that the document created additional work and was overwhelming. In addition, the misemployment of the framework calls into question the means of assessment and the "blind" application of the descriptive scales (Castellotti, 2012). These studies highlight the need for the implementation of CEFR to be flexible and comprehensive for different contexts. 
Another criticism is the assessment of the learners' abilities. Alderson (2001) argued that the learners' language proficiency descriptions were unclear, and it is difficult to interpret what learners actually have to perform. Some studies have also revealed difficulties related to aligning the language performance of learners with the tests. For instance, North (2000) found that the CEFR scale did not reflect learners' actual language competence but, rather, the teachers' views of that competence. According to Fulcher (2004), the CEFR reference level descriptions do not assess proficiency or cannot be a standard tool in language learning. Finally, a lack of comprehension in Can Do statements can affect the assessment of the learners' language proficiency (Wu \&Wu, 2007).

In a Thai EFL context, a few studies have explored the enactment of the CEFR framework. For example, Franz \& Teo (2017) examined secondary teachers' understanding of the CEFR and English language teaching. The findings indicated that the CEFR was known as the reference English proficiency level for teachers and learners. Still, the document was not adopted in the syllabus or English teaching and learning in the classroom (Franz \& Teo, 2017). Another study developed a ten-level reference framework known as FRELE-TH, which maintains the features of the CEFR descriptors of the assessment domain in the Thai context (Hiranburana et al., 2017). Moreover, Wudthayagorn (2018) mapped the CU-TEP to the Common European Framework of reference (CEFR) using a standard-setting methodology. More recently, research into perception and speaking competence showed that Thai preservice English teachers mostly agreed on the advantages of the innovative program CEFR-TBL (Phaisannan, Charttrakul, \& Damnet, 2019). Similarly, Kanchai (2019) also examined lecturers' perceptions about the CEFR and the application of the framework into classroom practices in a Thai EFL university. The findings revealed that Thai EFL lecturers clearly understood the concept of the CEFR, especially assessment-related aspects. Nevertheless, the results also showed that the participants had little understanding of the learning and teaching aspect, especially the action-oriented approach (Kanchai, 2019).

While the CEFR has been implemented to some extent in the Thai context (e.g., Hiranburana et al., 2017), it appears that English secondary teachers in Thailand have not fully embraced the framework into their classroom practice (Franz \& Teo, 2017). For instance, Kanchai (2019) found that Thai EFL lecturers had limited insights in the domains of CEFR learning and teaching approaches. This suggests that the implementation of the CEFR framework in a Thai context has not been as successful as anticipated. The current study aimed to examine why this might be the case by examining Thai preservice English teachers' perspectives and insights regarding the implementation of the CEFR. This study will provide a better understanding of practitioners' concerns and will raise awareness of the CEFR among curriculum designers, academics and policymakers. Two specific research questions were formulated for this study:

1. What insights do Thai preservice English teachers have regarding CEFR?

2. What are the perceptions of Thai preservice English teachers towards implementing CEFR into practice?

\section{Method}

\subsection{Participants and Context}

The current was conducted in three state universities in Mahasarakham, Sisaket, and Ubon Ratchathani, Northeastern Thailand. The participants were 200 Thai preservice teachers in English majors in the academic year 2020 - 2021. Participants were selected using the convenience sampling technique. All participants (32 males and 168 females) were aged between 20 to 25 years old and were studying in the fourth and fifth years. Fourth and fifth-year students from English majors were selected because the CEFR document was included in two of their compulsory subjects - Educational Measurement and Evaluation and English Language Curriculum.

\subsection{Instruments}

\subsubsection{Questionnaire}

A questionnaire was developed based on the CEFR document in Thai and English versions to address the research questions. The questionnaire included three sections and used a seven-point Likert scale to explore the views of the preservice English teachers. The first section gathered the participants' demographic information, including gender, age, years of study, and knowledge of the CEFR. The second section examined the participants' insights into CEFR. It focused on three elements: 1) principles for teaching and learning (items 1 to 7), 2) principles for assessment (items 8 to 13), and 3) principles for development and the application of reference level (items 14 to 20). Respondents were asked to score items on a seven-point Likert scale, ranging from strongly disagree (1) to strongly agree (7). The third section was the open-ended question. It asked the participants to share their opinions about the CEFR application in classroom practice. The questionnaire was 
validated using Cronbach's Alpha, which gave a reliability coefficient of 0.951 . The questionnaire was also validated by seven experts and piloted before the main study.

\subsubsection{Semi-Structured Interview}

Fifteen of the participants were randomly selected for the semi-structured interviews. The semi-structured interviews explored how those preservice English teachers felt about the implementation of the CEFR in their teaching practice. The duration of the interview was 15-20 minutes and was conducted after they completed the questionnaire. The interviews were also audiotaped and transcribed for content analysis. After the interviews, the transcripts were verified by the interviewees and the researcher. Then, the transcripts were coded and categorized into the four themes of the CEFR, including principles for teaching and learning, principles for assessment, principles for development and the application of reference level, and implementation in practice.

\subsection{Procedures}

A total of 200 participants were recruited to complete the 20 -item survey questionnaire. Then, semi-structured interviews were conducted with 15 randomly selected participants to collect in-depth data about the implementation of the CEFR in English language classrooms. A mixed-method design was used to collect quantitative and qualitative data in the current study to better identify the participants' attitudes and to provide a comparison between quantitative and qualitative data (Creswell, 2013). Moreover, the use of triangulation ensured the validity, reliability, and comprehension of the study.

\subsection{Data Analysis}

The data was collected using a questionnaire and semi-structured interviews. The responses for the 20 questionnaire items were analyzed using the IBM SPSS Statistics program. Content analysis was used to categorize the audio transcription of the interviews into four themes. Then, to ensure the accurate transcript of the interviewees, the interviews were emailed to the participants to validate their responses. The transcripts were also verified by a peer teacher who had background knowledge of the CEFR.

\section{Findings and Discussions}

The results of demographic information were divided into four parts: gender, years of the study, age, and knowledge of the CEFR. Of the 200 participants, $84 \%$ were female and $16 \%$ were male and all participants were aged between 20 to 25 years old. The respondents were studying in their fourth $(57 \%)$ or fifth year $(43 \%)$. The results also revealed that $67 \%$ of the respondents knew the CEFR document and $33 \%$ did not.

In response to RQ1, as shown in Table 1, the quantitative findings revealed that preservice teachers had a moderate level of understanding of the CEFR teaching and learning principles, with an average score of 4.26 or $60.85 \%$ (S.D. $=0.42)$. The highest mean $(5.60$ or $80 \%)$ was observed for the statement "CEFR is a guideline for developing English language teaching". This indicated that most participants understood that the CEFR document is a guideline for developing English language teaching. The results also revealed that the participants agreed that the CEFR is a vital document for curriculum design in English language teaching, with a mean value of 5.51 or $78.71 \%$. However, the participants disagreed with the statement that the framework can boost English for communication (mean $=2.36)$.

Table 1. Principles for teaching and learning $(n=200)$

\begin{tabular}{|c|c|c|c|c|}
\hline Item & Statements & mean & $\%$ & S.D. \\
\hline 1 & CEFR is a guideline for developing English language teaching. & 5.60 & 80.00 & 1.15 \\
\hline 2 & $\begin{array}{l}\text { CEFR is an essential document for curriculum design in English language } \\
\text { teaching. }\end{array}$ & 5.51 & 78.71 & 1.13 \\
\hline 3 & CEFR is a guidebook used to design teaching materials. & 5.37 & 76.71 & 1.14 \\
\hline 4 & CEFR can be used to enhance English for communication. & 2.36 & 33.71 & 1.05 \\
\hline 5 & $\begin{array}{l}\text { CEFR should be adapted to the local English curriculum in each context } \\
\text { (i.e., the English curriculum in Thailand). }\end{array}$ & 5.35 & 76.42 & 1.19 \\
\hline 6 & $\begin{array}{l}\text { CEFR is a handbook used for assisting learners in English language } \\
\text { learning. }\end{array}$ & 2.67 & 38.14 & 1.17 \\
\hline 7 & English learning activities should focus on plurilingualism. & 2.97 & 42.42 & 1.43 \\
\hline Total & & 4.26 & 60.85 & 0.42 \\
\hline
\end{tabular}


By contrast, the qualitative data revealed that the participants had only partial knowledge of the CEFR, particularly in the domain of learning and teaching. Indeed, many participants were aware that the CEFR was used as a guideline for English assessment but not for learning and teaching. This is illustrated in the following statements:

I never knew before that the CEFR is used for learning and teaching English. I have not taken a course about the framework, and the lecturer rarely mentions the CEFR in class. Nevertheless, I understand that the framework is used for English proficiency assessment. (Kevin)

I never perceive the framework as a guideline for teaching and learning. I just know that the CEFR is a criterion for measuring language proficiency. (Mia)

Such findings suggest that the university curriculum introduced the CEFR framework in terms of assessing English proficiency and focused only on teaching methodology, lesson planning, and learning materials, rather than adapting the CEFR descriptions to set learning objectives and outcomes. These results are consistent with previous studies reporting that English teachers rarely used the CEFR in practice (Duong \& Trinh, 2014; Franz \& Teo, 2017; Kitr \& Sulu, 2014). This may be because the implementation of CEFR has not been totally enforced and, moreover, the CEFR was only introduced in Thailand in 2014 (Franz \& Teo, 2017). Overall, the qualitative findings indicated that preservice teachers had little knowledge of the CEFR as a teaching and learning aid. Thus, the current results are partially consistent with previous studies that Thai English teachers' understanding of CEFR is lacking, particularly in knowledge related to the learning and teaching aspect (Díez-Bedmar \& Byram, 2019; Franz \& Teo, 2017; Kanchai, 2019).

The participants' understanding of the assessment domain in the CEFR framework is presented in Table 2. Most participants revealed a high level of insight into the CEFR assessment principles, with a mean of 5.16 or $73.71 \%$ (S.D. = 0.71). Notably, participants agreed that the aim of test development depends on the implementation of the CEFR in each context (mean $=5.37$ ). The results also showed that $76 \%$ of respondents agreed that the development of language evaluation should be aligned with the CEFR descriptions. While participants generally agreed with most statements in this section, the lowest scoring statement (with a mean of 4.96) related to English test assessments being verified by experts. Nevertheless, $70 \%$ of participants agreed with this statement.

Table 2. Principles for assessment $(n=200)$

\begin{tabular}{|c|c|c|c|c|}
\hline Item & Statements & mean & $\%$ & S.D. \\
\hline 8 & $\begin{array}{l}\text { The aim of test development depends on the implementation of the } \\
\text { CEFR in each context. }\end{array}$ & 5.37 & 76.71 & 1.05 \\
\hline 9 & $\begin{array}{l}\text { The development of language evaluation should be aligned with the } \\
\text { CEFR descriptions. }\end{array}$ & 5.32 & 76.00 & 1.11 \\
\hline 10 & English test assessments should be based on the CEFR document. & 5.03 & 71.85 & 1.15 \\
\hline 11 & English test assessments should be verified by experts. & 4.96 & 70.85 & 1.05 \\
\hline 12 & $\begin{array}{l}\text { The test designs should be consistent and aim to improve language } \\
\text { proficiency. }\end{array}$ & 5.14 & 73.42 & 1.03 \\
\hline 13 & $\begin{array}{l}\text { The results of the test can be used to identify English language } \\
\text { proficiency. }\end{array}$ & 5.15 & 73.57 & 1.10 \\
\hline Total & & 5.16 & 73.71 & 0.71 \\
\hline
\end{tabular}

Although the quantitative findings revealed a high level of understanding in the assessment aspect of the CEFR, the qualitative data indicated that preservice teachers had insufficient knowledge of the assessment domain. The participants reported that the CEFR is a criterion for language assessment, but they have no training on designing test assessment. The following statement supports this claim:

I understand that the CEFR is a criterion for measuring English proficiency from A1 beginner to C2. However, I have not been trained for designing test assessment based on CEFR. (Bloom)

This indicates that preservice teachers had only partial knowledge and little understanding of the CEFR assessment domain. These findings contrast with a previous study showing that Thai English teachers had a complete understanding of the CEFR in the area of assessment (Kanchai, 2019). This may be because the participants of the two studies had different education levels. Indeed, the participants in the current study were preservice teachers, whereas the participants in Kanchai (2019) were lecturers who likely had more opportunities to adopt the CEFR assessment in their pedagogical practice. 
As shown in Table 3, based on the quantitative data, the participants showed a high level of understanding regarding the use of reference level descriptions. Overall, the participants agreed with the statements, with an average mean of 4.92 or $70.28 \%$ (S.D. $=0.63$ ). More than $70 \%$ of participants indicated that the descriptions should bring transparency to English language teaching and should encourage English learning in all four skills $($ mean $=5.14)$. The statement with the lowest score related to the development of reference level descriptions to illustrate what learners know and their abilities at each level (mean $=4.73)$.

Table 3. Principles for the use of reference level descriptions $(n=200)$

\begin{tabular}{lllll}
\hline Item & Statements & mean & \% & S.D. \\
\hline 14 & $\begin{array}{l}\text { Developing CEFR reference level descriptions brings transparency to English } \\
\text { language teaching. }\end{array}$ & 5.14 & 73.42 & 1.20 \\
15 & $\begin{array}{l}\text { The development of reference level descriptions should illustrate what learners } \\
\text { know and their abilities at each level. }\end{array}$ & 4.73 & 67.57 & 1.09 \\
16 & $\begin{array}{l}\text { The development of CEFR reference level descriptions should designate learners' } \\
\text { proficiency related to indicators in the national curriculum. }\end{array}$ & 4.99 & 71.28 & 1.01 \\
17 & $\begin{array}{l}\text { CEFR reference level descriptions should aim to improve English all four skills } \\
\text { (listening, speaking, reading, writing). }\end{array}$ & 72.07 & 1.12 \\
18 & $\begin{array}{l}\text { CEFR reference level descriptions need to identify what learners can do at each } \\
\text { level. }\end{array}$ & 5.01 & 71.57 & 1.03 \\
19 & $\begin{array}{l}\text { CEFR reference level descriptions should explain what learners can achieve in } \\
\text { any skill. }\end{array}$ & 4.76 & 68.00 & 1.02 \\
CEFR reference level descriptions can be a guideline for English language & 4.75 & 67.85 & 1.12 \\
evaluation. & & $\mathbf{4 . 9 2}$ & $\mathbf{7 0 . 2 8}$ & $\mathbf{0 . 6 3}$
\end{tabular}

However, once again, the qualitative data analysis did not support the quantitative findings. Indeed, the content analysis of the interviews revealed that the participants did not know the CEFR descriptions. The following excerpts support this claim:

\section{I do not know anything about the CEFR reference descriptions. (Leon) \\ I never heard about CEFR descriptions before. (Alice) \\ I do not know about the CEFR descriptions. (Eva)}

These excerpts indicate that preservice English teachers had an inadequate understanding of CEFR reference level descriptions. The reason for this may be twofold. First, student teachers may be unfamiliar with the framework. Second, the participants were not full-time teachers; hence they do not have adequate time or opportunity to put the CEFR into practice. These results are consistent with a study by Tosun \& Glover (2020), who found that the teachers were not confident to adapt the framework in class because they do not know how to integrate the descriptions into their language test assessment. As such, these results suggest that student teachers require additional CEFR training, especially in the area of using reference level descriptions.

To examine if Thai preservice teachers implement CEFR into practice, the interview data were analyzed and categorized into three themes; learning and teaching, assessment, and the use of reference level descriptions. In the area of learning and teaching, most of the participants reported that they were unaware of the action-oriented approach, and only two of the participants used the CEFR in their learning and teaching practices. These participants stated that they had partially adopted the framework to set learning objectives and outcomes that highlighted communication. This unsuccessful CEFR implementation in the classroom might be explained by the preservice English teachers' insufficient knowledge of using the action-oriented and plurilingual approach, which means they are uncomfortable (and, perhaps, unable) to use the CEFR in their classroom practice. Moreover, the English language courses provided in the Thai educational system traditionally depend on a grammar-translation teaching method. Therefore, preservice teachers may not have the opportunity to adapt and use the CEFR approaches. This is illustrated in the following statements:

I have used the descriptions to set the learning objectives in my lesson plans. I think it is useful for me to design learning activities. (Kevin) 
I have heard about the CEFR oriented approach a few times. I also try to adapt the approach for designing learning activities in my classroom because I teach a supplementary course, English for communication. Nonetheless, I do not know very much about the approach. (Matt)

Overall, the results indicated that the student teachers had a poor understanding of the CEFR in learning and teaching approaches because they were inexperienced with the document. The results are in line with qualitative research by Yusoff \& Abdul (2020), who stated that the teachers lacked sufficient support to implement the CEFR in English classrooms. This suggests that teaching English in the Thai context still focuses on traditional teaching rather than communicative teaching.

The results also revealed that the participants perceived the CEFR as a criterion for test assessment. Nevertheless, they were unable to provide additional details and did not apply the CEFR to measure English test performance in class. Furthermore, the participants reported that they had never adopted the descriptions for designing test assessments. This may be because the student teachers are not trained in how to design tests based on CEFR principles, as shown in the excerpt below:

I heard my lecturer mention the CEFR document many times, but I am not into the framework because there is no class for training about the CEFR. For my understanding, it is used only to measure English test assessment. (Nina)

This excerpt indicates that, despite understanding the CEFR assessment, the participants are unable to implement it in an authentic context. Indeed, the current results suggest that the participants may understand the assessment principle but lack practice in real settings. Preservice English teachers may therefore require further training on assessment language in relation to CEFR, which is consistent with previous studies (Díez-Bedmar \& Byram, 2019; Hai, 2018; Kitr \& Sulu, 2014; Tiep, 2017)

The CEFR reference level descriptions emphasize the use of Can-Do descriptors that are used for describing language proficiency in five skills - listening, reading, writing, spoken interaction, and spoken production - at six scales $(\mathrm{CoE}, 2001)$. The interview revealed that the student teachers had partially adopted the descriptions in practice, as demonstrated in the excerpt below:

The descriptions can be used to identify what language learners can do in each skill. While I may briefly consult the Can-Do descriptors' idea, I do not apply the concept into practice. (Nadia)

This excerpt illustrates that the participants lacked some knowledge about Can-Do descriptors, perhaps due to an insufficient understanding of CEFR reference level descriptions. In addition, as previously mentioned, the participants were not full-time teachers; hence, they may not have adequate time or opportunity to put the CEFR into practice. The findings are partially in line with a study by Yüce \& Mirici (2019), who indicated that insufficient hours affected the unsuccessful implementation of CEFR in class. Therefore, these results also indicate that student teachers require additional CEFR training in the area of using reference level descriptions.

In conclusion, the qualitative analysis revealed that Thai preservice English teachers had only partially implemented the CEFR and had insufficient knowledge of CEFR implementation. The findings suggest that student teachers have limited opportunities to adapt the CEFR in pedagogical practice, mainly because they are not in-service teachers. These results are consistent with previous studies (Díez-Bedmar \& Byram, 2019; Franz \& Teo, 2017; Kanchai, 2019), showing that CEFR had only been partially incorporated into English language teaching and learning in several countries. Together, these findings suggest that preservice English teachers need further training in all domains of the CEFR.

\section{Conclusion}

The current study investigated Thai preservice English teachers' insights into CEFR and explored the implementation of the CEFR in classroom practice. Overall, the quantitative results revealed that preservice English participants had moderate knowledge of CEFR. Knowledge of the assessment domain was greater than knowledge in the domain of reference level descriptions and the teaching and learning approach. Regarding the assessment domain, Thai preservice teachers showed a high level of understanding of CEFR. However, the qualitative data analysis revealed that preservice English teachers appeared to have only partial knowledge of CEFR, including in the domain of assessment. Indeed, preservice English teachers understood the CEFR but could not apply any domains in an authentic context. This may be because they have an incomplete understanding of the framework or have no experience in implementing the framework's principles in a real teaching context. These findings are partially consistent with previous studies that Thai English teachers lacked understanding of the CEFR, particularly the learning and teaching aspect (Franz \& Teo, 2017; Kanchai, 2019). Moreover, the participants did not apply the reference level descriptions to design Can Do descriptors for their pedagogical practice. Thus, the 
current study results indicate that CEFR training should be incorporated into the university courses and curricula for student teachers. The findings also show the importance of extensive training programs related to the CEFR.

\section{Implications and Suggestions for Future Studies}

The scope of the current study was limited to preservice teachers at public universities in Northeastern Thailand. Therefore, these results may not fully represent preservice English teachers across the nation. Future studies may include other practitioners, namely in-service teachers, school directors, policymakers, as well as various settings, such as primary and secondary schools and higher education institutions. Another interesting area of research is to explore the impact of aligned learning and teaching, with a focus on English teachers, using other data collection methods, such as observation and video recording of classroom practices.

To conclude, policymakers need to fully enforce using the CEFR in course syllabuses and also encourage English teachers to adapt it to their pedagogical practices. Moreover, CEFR training programs should also be provided to ensure that all stakeholders, including preservice teachers, understand how the CEFR can be used in all domains.

\section{References}

Alderson, J. C. (2007). The CEFR and the need for more research. The Modern Language Journal, 91(4), 659-663. https://doi.org/10.1111/j.1540-4781.2007.00627_4.x

Alih, N. A. C., Yusoff, M. A. M., \& Abdul, A. H. (2020). Teachers'Knowledge and Belief on the CEFR Implementation in Malaysian ESL Classroom. International Journal of Multidisciplinary and Current Educational Research (IJMCER), 2(5), 126-134.

Apelgren, B. M., \& Baldwin, R. (2018). Can Do and Cannot Do - CEFR inspired examination and assessment in a Swedish higher education context. Apples - Journal of Applied Language Studies, 12(2), 19-35. https://doi.org/10.17011/apples/urn.201809144127

Athiworakun, C., Vathanalaoha, K., Thongprayoon, T., Rajprasit, K., \& Yaemtui, W. (2018). SWU-SET as a CEFR standardized English Test. Journal Language and Research, 9(2), 261-267. https://doi.org/10.17507/jltr.0902.06

Castellotti, V. (2012). Academic perspectives from France. In M. Byram \& L. Parmenter (Eds.), The Common European Framework of Reference: The globalisation of language education policy (pp. 45-52). Bristol: Multilingual Matters.

Celik, S. (2013). Plurilingualism, pluriculturalism, and the CEFR: Are Turkey's foreign language objectives reflected in classroom instruction? Procedia - Social and Behavioral Sciences, 70(1), 1872-1879. https://doi.org/10.1016/j.sbspro.2013.01.265

Council of Europe (2018). Common European Framework of Reference for Languages: Learning, teaching and assessment. Companion volume with new descriptors. Council of Europe, Language Policy Programme. Strasbourg. Retrieved from https://www.coe.int/lang-cefr

Council of Europe. (2001). Common European Framework of Reference for Languages: Learning, Teaching, and Assessment. Cambridge, UK: Cambridge University Press.

Council of Europe. (2005). Survey on the use of the Common European Framework of Reference for Languages (CEFR): Synthesis of results. Retrieved from https://www.coe.int/t/dg4/linguistic/Source/Surveyresults.pdf

Creswell, J. W. (2013). Research design: Qualitative, quantitative, and mixed Methods approaches. Thousand Oaks, CA: Sage.

De Mejía, A.-M. (2011). The national bilingualism programme in Colombia: Imposition or opportunity? Apples - Journal of Applied Language Studies, 5(3), 7-17.

Díez-Bedmar, M. B., \& Byram, M. (2019). The current influence of the CEFR in secondary education: teachers' perceptions. Language, Culture and curriculum, 32(1), https://doi.org/10.1080/07908318.2018.1493492

Duong, D. T., \& Trinh, Q. L. (2016). Lecturers and students' perception of EFL policy and practice at a higher education institute. Can Tho University Journal of Science.

EF English Proficiency Index. (2016). Proficiency Trend. Retrieved from https://www.ef.co.th/epi/regions/asia/thailand/ 
Faez, F., Majhanovich, S., Taylor, S., Smith, M., \& Crowley, K. (2011). The power of “Can Do" statements: Teachers' perceptions of CEFR-informed instruction in French as a second language classrooms in Ontario. The Canadian Journal of Applied Linguistics, 14(2), 1-19.

Franz, J., \& Teo, A. (2017). 'A2 is Normal' - Thai secondary school English teachers' encounters with the CEFR. RELC Journal, 49(3), 322-338. https://doi.org/10.1177/0033688217738816

Fulcher, G. (2004). Deluded by artifices? The Common European Framework and harmonization. Language Assessment Quarterly, 1(4), 253-266. https://doi.org/10.1207/s15434311laq0104_4

Fulcher, G., \& Davidson, F. (2007). Language testing and assessment: An advanced resource book. Routledge.

Hai, L. T. T. (2018). Impacts of the CEFR-Aligned learning outcomes implementation on assessment practice. Hue University Journal of Science: Social Sciences and Humanities, 127(6), 87-99. https://doi.org/10.26459/hueuni-jssh.v127i6B.4899

Hiranburana, K., Subphadoongchone, P., Tangkiengsirisin, S., Phoochaeoensil, S., Gainey, J., Thogsngsri, J., ... Taylor, P. (2017). A Framework of Reference for English Language Education in Thailand (FRELE-TH)—based on the CEFR, The Thai experience. LEARN Journal, 10(2), 90-119.

Jerald, G. G., \& Shah, P. M. (2018). The Impact of CEFR-Aligned Curriculum in the Teaching of ESL in Julau District: English Teachers' Perspectives. International Journal of Innovative Research and Creative Technology, 4(6).

Kanchai, T. (2019). Thai EFL University Lecturers' Viewpoints towards Impacts of the CEFR on their English Language Curricula and Teaching Practice. NIDA Journal of Language and Communication, 24, 23-42.

Kır, E., \& Sülü, A. (2014). Language Teachers' views on CEFR. International Online Journals of Education and Teaching (IOJET), 1(5), 358-364.

Kok, N. M., \& Abd Aziz, M. S. (2019). English language teachers' perceptions on the Implementation of CEFRaligned curriculum among Primary school in Malaysia.

McNamara, T. (2011). Managing learning: Authority and language assessment. Language Teaching, 44(4), 500-515. https://doi.org/10.1017/S0261444811000073_

Minh Ngo, X. (2017). Diffusion of the CEFR among Vietnamese Teachers: A mixed methods investigation. Asean EFL Journal, 19(1), 7-32.

Minister of Education. (2014). Ministry of Education announcement regarding the English language teaching reform policy [ebook]. Bangkok: English Language Institute, The Office of Basic Education Committee.

Ministry of Education. (2014). English language teaching reform policy (pp. 1-20). Bangkok, Thailand: Office of The Basic Education Commission Ministry of Education.

Morrow, K. (Ed.). (2004). Insights from the Common European Framework. Oxford: Oxford University Press.

Musoeva, A. (2019). What do Uzbekistani EFL teachers know and believe about the usefulness of the CEFR? International Journal of Academic Research and Reflection, 7(6).

Nakatani, Y. (2012). Exploring the Implementation of the CEFR in Asian Contexts: Focus on Communication Strategies. Social and Behavioral Sciences, 46, 771-775. https://doi.org/10.1016/j.sbspro.2012.05.196

North, B. (2000). The development of a common framework scale of language proficiency. New York, Peter Lang. https://doi.org/10.3726/978-1-4539-1059-7

North, B. (2014). The CEFR in practice. Cambridge: Cambridge University Press.

North, B., \& Jones, N. (2009). Further Material on Maintaining Standards across Languages, Contexts and Administrations by exploiting Teacher Judgment and IRT Scaling. Strasbourg: Council of Europe.

North, B., Oretega, A., \& Sheehan, S. (2010). A core inventory for general English. British Council: EAQUALS.

Phaisanan, T., Charttrakul, K., \& Damnet, A. (2019). The CEFR-TBL in Fostering Thai Pre-service Teachers' English speaking Ability Using the Peer Interview Task. Advances in Language and Literacy Studies, 10(5), 10-19. https://doi.org/10.7575/aiac.alls.v.10n.5p.10

Savski, K. (2019). Putting the Plurilingual/Pluricultural back into CEFR: Reflecting on Policy Reform in Thailand and Malaysia. Journal of Asia TEFL, 16(2), 644-652. https://doi.org/10.18823/asiatefl.2019.16.2.13.644 
Tiep, N. N. (2017). EFL Teachers' perceptions towards the use of CEFR-V. European Journal of English Language Teaching.

Topal, İ. H. (2019). CEFR-oriented probe into pronunciation: Implications for language learners and teachers. Journal of Language and Linguistic Studies, 15(2), 420-436. https://doi.org/10.17263/jlls.586087

University of Cambridge. (2011). Using the CEFR Principles of Good Practice. Cambridge: Cambridge University Press.

Ünlücan Tosun, F., \& Glover, P. (2020). How do school teachers in Turkey perceive and use the CEFR? International Online Journal of Education and Teaching (IOJET), 7(4), 1731-1739.

Uri, N. F. M., \& Abd Aziz, M. S. (2018). Implementation of CEFR in Malaysia: Teachers' awareness and the Challenges. 3L: The Southeast Asian Journal of English Language Studies, 24(3), 168-183. https://doi.org/10.17576/3L-2018-2403-13

Wu, J. R. W., \& Wu R. Y. F. (2007). Using the CEFR in Taiwan: The perspective of a local examination board. The Language Training and Testing Center Annual Report 56. Taipei: National Taiwan University.

Wudthayagorn, J. (2018). Mapping the CU-TEP to the Common European Framework of Reference (CEFR). Language Education and Acquisition Research Network Journal, 11(2), 163-180.

Yakışık, B. Y., \& Gürocak, F. Ü. (2018). A Comparative Study of perceptions about the 'Common European Framework of Reference' among EFL teachers working at state and private schools. International Online Journal of Education and Teaching (IOJET), 5(2), 401-417.

Yüce, E., \& Mirici, İ. H. (2019). A qualitative inquiry into the application of 9th grade EFL program in terms of the CEFR. Journal of Language and Linguistic Studies, 15(3), 1171-1187. https://doi.org/10.17263/jlls.631560

\section{Copyrights}

Copyright for this article is retained by the author(s), with first publication rights granted to the journal.

This is an open-access article distributed under the terms and conditions of the Creative Commons Attribution license (http://creativecommons.org/licenses/by/4.0/). 